\title{
MODULAR MEASURING SYSTEM FOR ASSESSMENT OF THE THYROID GLAND FUNCTIONAL STATE
}

\author{
V. Rosík, M. Tyšler, J. Švehlíková, J. Ždiňák \\ Institute of Measurement Science, Slovak Academy of Sciences, Dúbravská cesta 9, 841 04, Bratislava, Slovakia \\ E-mail:umerrosi@savba.sk,Phone: +4212 59104553,Fax: +421254775943
}

\begin{abstract}
Abstrakt V článku je prezentovaný distribuovaný modulárny systém BioLab určený na biofyzikálne vyšetrenia umožňujúce zistenie funkčného stavu štítnej žl'azy. Systém BioLab je pozostáva zo štandardného PC vo verzii notebooku alebo stolného počítača, ku ktorému sú prostredníctvom siete Ethernet pripojené dva inteligentné snímače. Tieto snímače sú programované a riadené pomocou PC a umožňujú meranie vybraných biosignálov l'udského kardivaskulárneho a neuromuskulárneho systému, ktoré sú ovplyvňované produkciou hormónov štítnej žlazy. Zaznamenané biosignály sú spracované v PC a na ich základe sú vyhodnotené periférne ukazovatele, ktoré charakterizujú funkčný stav štítnej žlazy.
\end{abstract}

Summary Distributed modular system BioLab for biophysical examinations enabling assessment of the thyroid gland functional state is presented in the paper. The BioLab system is based on a standard notebook or desktop PC connected to an Ethernet-based network of two smart sensors. These sensors are programmed and controlled from PC and enable measurement of selected biosignals of the human cardiovascular and neuromuscular system that are influenced by the production of thyroid gland hormones. Recorded biosignals are processed in a PC and peripheral indicators characterizing thyroid gland functional state are evaluated.

\section{INTRODUCTION}

Development of a measuring system using Ethernet as a communication interface between a few smart sensors and a controlling PC offers the possibility to build local area or even wide area configurations of open, modular systems for biomedical applications. They allow immediate acquiring of various types of medical information that was previously obtained off-line or by several independent measuring devices. In this way the networked solution saves time and costs in medical facilities and improves quality of medical care.

Based on previous experience with the diagnostic method [1], the aim of the presented work was to develop hardware and software components of a modular networked measuring system for laboratory biophysical examinations allowing to assess patient's thyroid gland functional state using peripheral indicators of his/her cardiovascular and neuromuscular systems [2]. In comparison with other, mainly biochemical methods, such examinations are non-traumatizing and in most cases provide enough diagnostic information at much lower costs.

\section{MATERIAL AND METHOD}

BioLab is distributed modular measuring system for biophysical examinations that consists of a set of smart sensors and a controlling PC. All these components are connected to the Ethernet network. In principle, configuration of the system can be local or distributed depending on the requirements of the user in the medical institution. Number of connected sensors is generally not limited and is software configurable. Reasonable number of sensors depends on particular application.

Core of each BioLab smart sensor module (Fig.1) is Analog Devices $\mathrm{AD} \mu \mathrm{C} 812$ microcontroller chip with a measuring unit and interface control completed with a RS $232 \mathrm{C}$ to TCP/IP converter with RJ45 Ethernet connector enabling connection of the module to a data processing PC via the Ethernet network. For the patient safety, module is optically isolated from the Ethernet and is powered by Li-Ion battery enabling approximately 6 hours of measurement. Due to advanced power management, average battery operating time is about 5 working days, however, device can be operated also during the battery charging from an isolated charger.

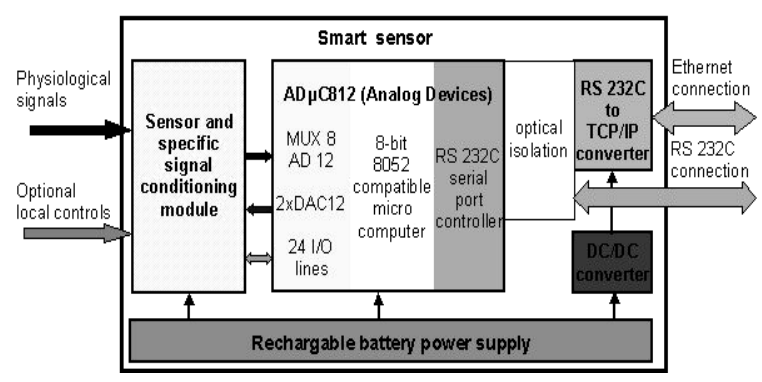

Fig. 1. Simplified block scheme of BioLab smart sensor modules.

Two smart sensors were developed for noninvasive assessment of the functional state of human thyroid gland: BioLab ATR sensor for Achilles tendon reflex measurement and BioLab STI sensor for measurement of systolic time intervals. Both sensors are based on the previously presented 
concept [2] of a network-based modular measuring system.

\section{BioLab ATR smart sensor}

This sensor is shown in Fig. 2 and enables noninvasive revealing of the effect of thyroid gland hormones on the neuromuscular system. Increased production of thyroid gland hormones induces faster actions of the neuromuscular system and vice versa. Based on this relation, dynamics of Achilles tendon reflex is evaluated as one of peripheral indicators of thyroid gland function.

Time intervals of the Achilles tendon reflex are measured by a non-contact, optoelectronic device sensing the movement of the sole. The reflex is initiated by a neurological hammer and the tendon jerk causes motion of the sole that is scanned by an IR optoelectronic system as the ATR signal. Input module of the sensor contains three infra-red emitting diodes and a photo-transistor sensing the radiation reflected by the moving sole. Switching of the emitting diodes and sampling of the photo detector output is controlled directly by the $\mathrm{AD} \mu \mathrm{C} 812$ chip of the smart sensor. Intensity of the reflected radiation depends on the distance between the sensor and the sole. Recorded ATR signal is electronically synchronized with the time instant of the stimulus, sampled with $1 \mathrm{kHz}$ rate and sent over the Ethernet to the processing PC.

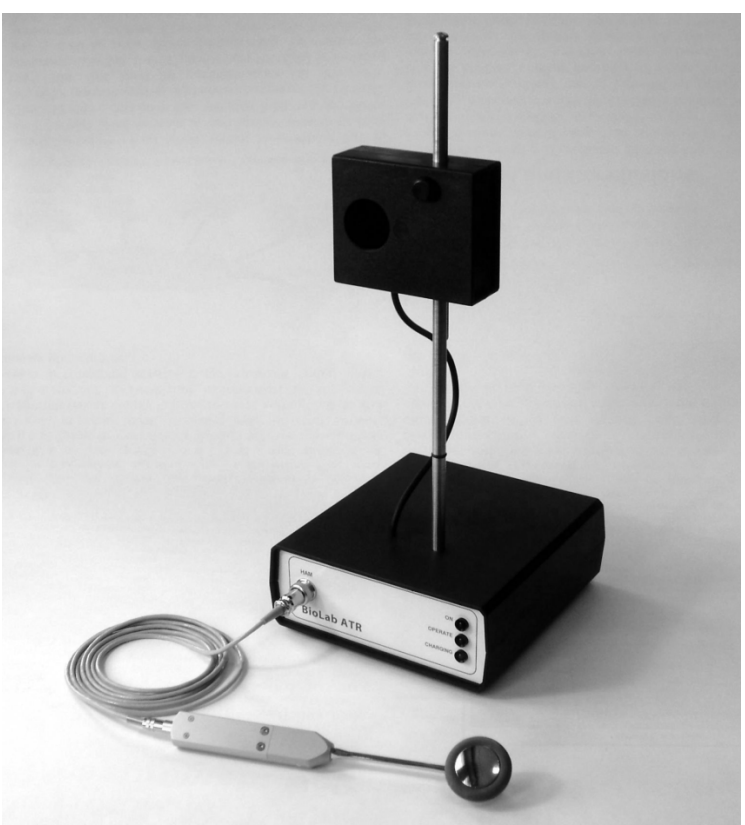

Fig. 2. BioLab ATR smart sensor module with optoelectronic sole movement sensor and synchronized stimulating neurologic hammer.

\section{BioLab STI smart sensor}

BioLab STI (Fig.3) is a 3-channel sensor developed to obtain information on cardiovascular dynamics influenced by thyroid gland hormones. It enables measurement of one electrocardiographic lead (ECG, mostly standard lead II), phonocardiogram (PCG, frequency band 1) and carotidogram, i.e. signal of the carotid pulse wave (CAR).

ECG signal is sensed by a set of 3 disposable $\mathrm{Ag}-\mathrm{AgCl}$ electrodes, programmable gain of the ECG channel is from 0 to 10200 and frequency range is $0.16 \mathrm{~Hz}-1 \mathrm{kHz}$. Active patient neutralization is used to improve common-mode signal rejection ratio.

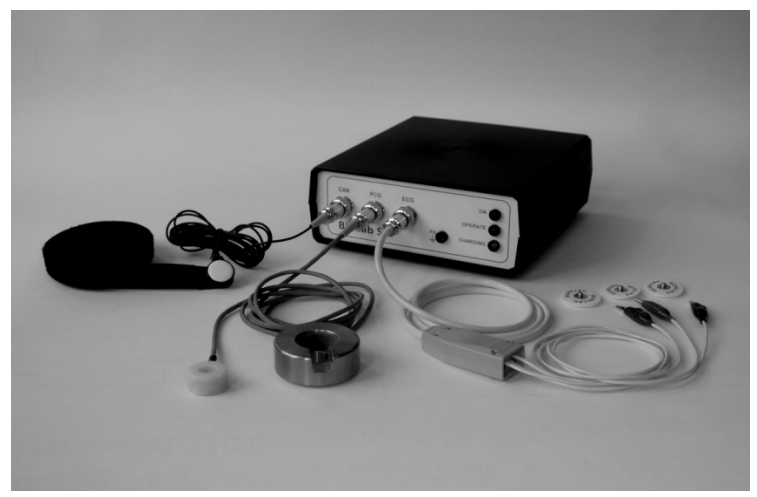

Fig. 3. BioLab STI smart sensor module with ECG electrodes, cardio microphone and piezzo-electric sensor of the carotid pulse wave.

ADInstruments MLT 201 Cardio Microphone is used for recording of the PCG heart sounds. PCG signal is amplified with programmable gain from 0 to 10000 and is processed in a band-pass filter with frequency $\mathrm{f}=35 \mathrm{~Hz}$ and symmetric band attenuation $\mathrm{B}=-12 \mathrm{~dB} /$ octave (band F1 by Maase - Weber).

ADInstruments MLT 1010 piezzo-electric transducer is used for converting carotid pulse wave signal CAR into an electrical signal. CAR channel has also programmable gain from 0 to 450 and frequency range $0.16 \mathrm{~Hz}-1 \mathrm{kHz}$.

For patient safety, there is an optical isolation in all channels that is placed between the signal preamplifier and the programmable amplifier. After proper amplification, all three signals are sampled by the $\mathrm{AD} \mu \mathrm{C} 812$ chip with $1 \mathrm{kHz}$ (or $500 \mathrm{~Hz}$ ) rate. Microcomputer also provides optimal gain setting in all channels. Sampled data are sent over the Ethernet network to the PC where they are evaluated.

\section{BioLab application software}

BioLab Application software is a 32-bit application running under Windows XP operating system and developed in MS Visual C++ and Microsoft Foundation Class library with graphical user interface. It allows full control of the connected smart sensors and enables real-time monitoring of measured biosignals, their visualization on computer display and recording. Comfortable and easy to use measuring program includes resources for adjustment of all sensors parameters, such as sampling period, gain of amplifiers or Ethernet communication parameters. 
Communication between smart sensors and controlling PC is over the Ethernet network and is based on a client-server model and TCP/IP network protocol. Smart sensors present servers and PC is connected as a client when needed. Only one single PC can be simultaneously connected to each smart sensor.

Recorded biosignals are automatically processed to obtain parameters needed for evaluation of patient's thyroid gland functional state.

To assess parameters of the neuromuscular system functionality, contraction time TK, relaxation time TR and half-relaxation time TH are evaluated from the ATR signal (Fig.4).

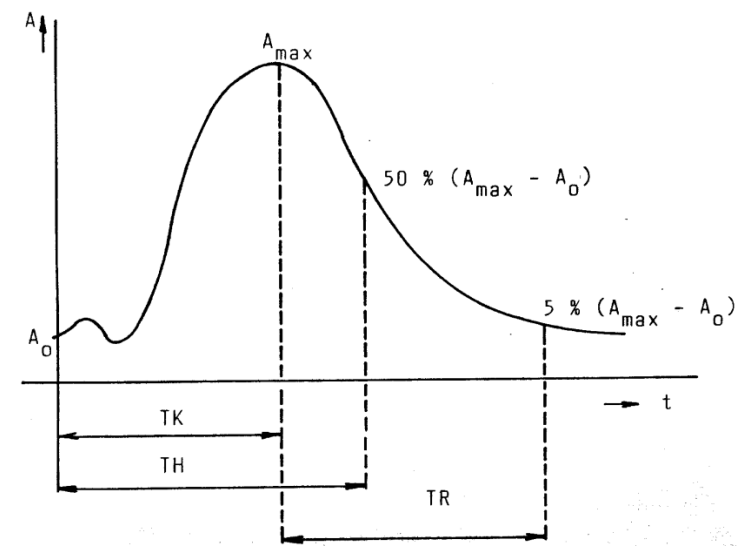

Fig. 4. Evaluation of the contraction, half relaxation and relaxation times from the ATR signal.

Two parameters are evaluated from cardiovascular recordings: pre-ejection phase interval (PEP) and heart rate (HR). To obtain PEP, time interval of the electro-mechanic systole QS2 and ejection time of the left ventricle LVET is estimated first. Duration of the PEP is then obtained as $\mathrm{PEP}=\mathrm{QS} 2$-LVET. Finally, heart rate is estimated from the mean time interval between consecutive QRS complexes in the ECG signal (Fig.4).

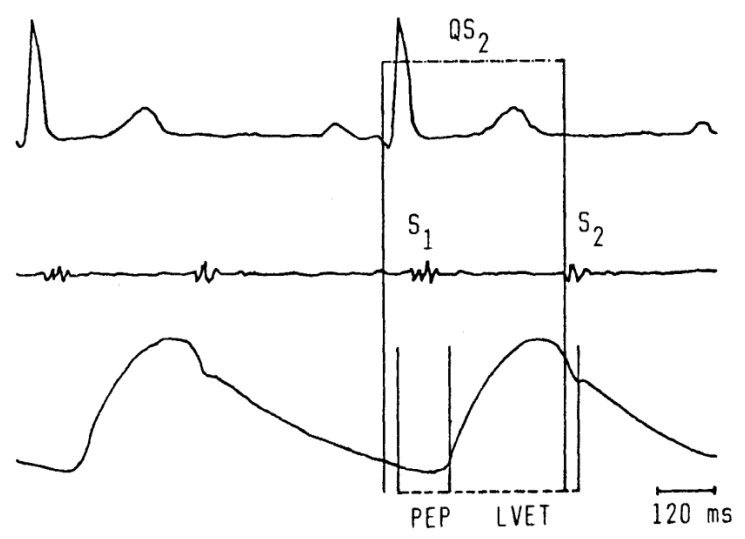

Fig. 5. Evaluation of the pre-ejection phase interval PEP. Results from several measurements are averaged, presented in numeric and graphical form and classified according pre-programmed diagnostic criteria. Functional state of the thyroid gland is characterized by overall thyroxin $\mathrm{T} 4$ level that can be estimated and classified using a set of regression equations [3]. Several equations using desired combination of available peripheral parameters can be used, however, generally the more parameters are used in the equation, the higher is the reliability of the estimate.

Results of the classification are displayed in a circular diagram (Fig.6) showing values of all evaluated peripheral parameters and overall thyroxin T4 level relatively to a normal range (area between the circles in Fig.6).
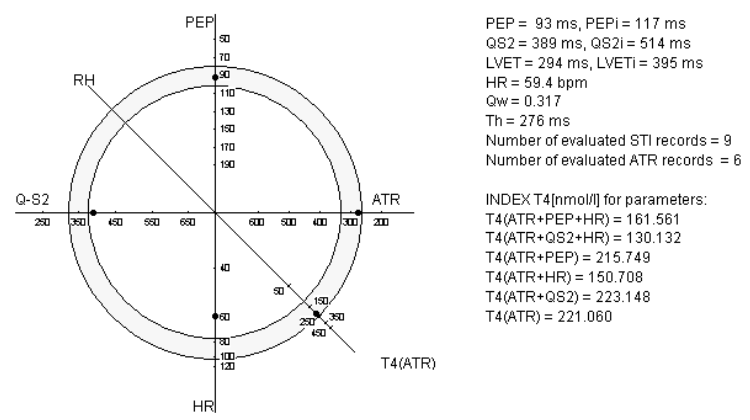

Fig. 6. STI and ATR evaluation and estimated T4 hormone level displayed in a circular diagram.

\section{RESULTS}

Presented system, has been successfully used in the clinic for routine screening of thyroid gland patients as well as a learning tool in courses of biomedical engineering. It combines simplicity of the measuring method with advanced technology to obtain reliable measurements.

In Fig. 7 there is a snapshot of the computer screen during the examination of the neuromuscular system after the ATR time intervals were evaluated.

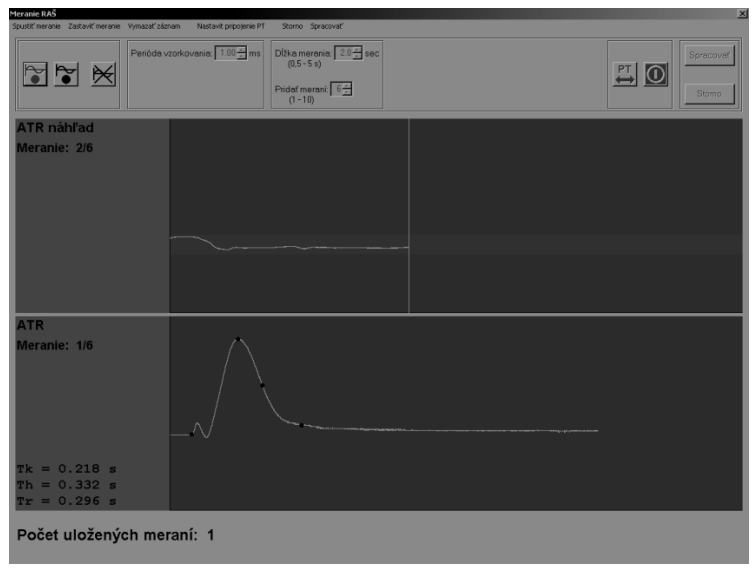

Fig. 7. Screenshots of the evaluation of the ATR signal with marked time instants TK, TH and TR. 
In Fig.8 there is a snapshot of the computer screen during the examination of the cardiovascular system, after the cardiovascular signals were processed and systolic time intervals were evaluated.

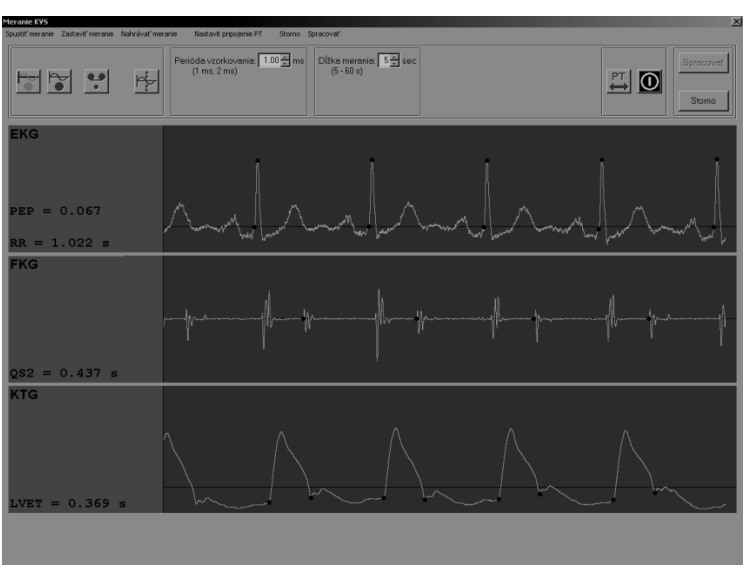

Fig. 8. Screenshot of the evaluation of cardiovascular signals. Automatically detected time instants $Q$ and $R$ in the ECG signal, S2 in the PCG signal, upstroke and incisure in the CAR signal are marked in the recordings and used for computation of systolic time intervals.

\section{CONCLUSIONS}

Presented system was proposed for fast noninvasive screening tests enabling to assess the functional state of the thyroid gland. From the users' point of view, another advantage of the system is it variability and possibility to extend it to other examinations. Modular concept of the system cuts the cost and time for its development and implementation and enables to adapt its configuration according to the user requirements. Possible future extension of the system depends on the response from the medical and biomedical engineering community.

\section{Acknowledgement}

This work was supported by grant 51-51-901400/2002 from the Slovak Academy of Sciences and grant APVT-51-017802 from the Grant Agency for Science and Technology.

\section{REFERENCES}

[1] P. Kneppo, E. Kužma, V. Oravec, V. Rosík, Physician \& Technology journal (Lékař a technika), 20, 97 (1989).

[2] V. Rosík, M. Tyšler, J. Ždiňák, R. Rášo, Proceedings of the 4th International Conference on Measurement. VEDA Bratislava, (2003).

[3] S. Váňa, R. Reisenauer, J. Němec, J. Bednář, Internal medicine (Vnitřní Lékařství), 31, 474 (1985). 